\title{
Cephalopod fauna of the Pacific Southern Ocean using Antarctic toothfish (Dissostichus mawsoni) as biological samplers and fisheries bycatch specimens
}

\author{
José P. Queirós ${ }^{\mathrm{a}, *}$, Jaime A. Ramos ${ }^{\mathrm{a}}$, Yves Cherel ${ }^{\mathrm{b}}$, Marco Franzitta ${ }^{\mathrm{c}}$, Bernardo Duarte ${ }^{\mathrm{d}, \mathrm{e}}$, \\ Rui Rosa ${ }^{c}$, Filipa Monteiro ${ }^{f, g}$, Andreia Figueiredo ${ }^{e, h}$, Jan M. Strugnell ${ }^{i}$, Yuki Fukuda ${ }^{j}$, \\ Darren W. Stevens ${ }^{\mathrm{k}}$, José C. Xavier ${ }^{\mathrm{a}, 1}$ \\ ${ }^{\text {a }}$ University of Coimbra, MARE - Marine and Environmental Sciences Centre, Department of Life Sciences, 3000-456, Coimbra, Portugal \\ ${ }^{\mathrm{b}}$ Centre d'Etudes Biologiques de Chizé, UMR 7372 du CNRS-La Rochelle Université, 79360, Villiers-en-Bois, France \\ ${ }^{\mathrm{c}}$ Laboratório Marítimo da Guia, MARE - Marine and Environmental Sciences Centre, Faculty of Sciences, University of Lisbon, Lisbon, Portugal \\ ${ }^{\mathrm{d}}$ MARE - Marine and Environmental Sciences Centre, Faculdade de Ciências da Universidade de Lisboa, Campo Grande, 1749-016, Lisbon, Portugal \\ e Departamento de Biologia Vegetal, Faculdade de Ciências da Universidade de Lisboa, Campo Grande, 1749-01, Lisbon, Portugal \\ ${ }^{\mathrm{f}}$ Centre for Ecology, Evolution and Environmental Changes (cE3c) - Faculty of Sciences, University of Lisbon, Lisbon, Portugal \\ ${ }^{\mathrm{g}}$ Linking Landscape, Environment, Agriculture and Food (LEAF), Instituto Superior de Agronomia, University of Lisbon, Lisbon, Portugal \\ ${ }^{\mathrm{h}}$ BIOISI - Biosystems and integrative sciences institute, Faculty of Sciences, University of Lisbon, Lisbon, Portugal

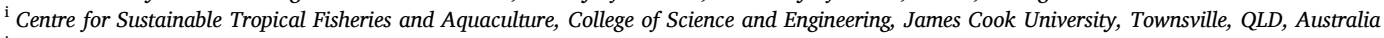 \\ ${ }^{\mathrm{j}}$ Snow Parrot Ltd, Richmond, Tasman, New Zealand \\ ${ }^{\mathrm{k}}$ NIWA - National Institute for Water and Atmospheric Research, 301 Evans Bay Parade, Hataitai, Wellington, 6021, New Zealand \\ ${ }^{1}$ British Antarctic Survey, NERC, High Cross, Madingley Road, CB3 OET, Cambridge, United Kingdom
}

\section{A R T I C L E I N F O}

\section{Keywords:}

DNA barcoding

Amundsen Sea

D'Urville Sea

Cephalopoda

Stable isotopes

Trophic ecology

\begin{abstract}
A B S T R A C T
Cephalopods are an important component of Southern Ocean food webs but studies analysing their habitat and trophic ecology are scarce. Here, we use the Antarctic toothfish Dissostichus mawsoni as a biological sampler of Southern Ocean's cephalopods in the Ross, Amundsen, and D'Urville Seas. Ten cephalopod taxa were identified in the diet of the Antarctic toothfish, with Pareledone turqueti and Moroteuthopsis longimana being the only species present in all the three studied areas. DNA analysis conducted on squid flesh samples allowed identification of eight and two specimens of Mesonychoteuthis hamiltoni and M. longimana, respectively, proving this technique as a potential tool to improve the knowledge of cephalopods biodiversity and biogeography in the Southern Ocean. Stable isotopes were used to compare the habitat $\left(\delta^{13} \mathrm{C}\right)$ and trophic ecology $\left(\delta^{15} \mathrm{~N}\right)$ between two life-stages of the two most abundant squid species (M. longimana and Psychroteuthis glacialis) from the D'Urville Sea (both squid species) and Amundsen Sea (only P. glacialis). Higher $\delta^{13} \mathrm{C}$ values in $M$. longimana suggest that this species inhabits waters near the Antarctic Polar Front, with incursions into sub-Antarctic waters, whilst $P$. glacialis spends its entire life in Antarctic waters. The most recently deposited part of the beak is enriched in ${ }^{15} \mathrm{~N}$ suggesting an increase in trophic level during squid growth. These results give us the first insights into the bathyal distribution of cephalopods in the Amundsen and D'Urville Seas, as well as into the ontogenetic changes of two of the most consumed squid species by top predators in this region. Such results are an important step towards improving the biogeography of Antarctic cephalopods, being of utmost importance to understand the biodiversity, food web structure, and functioning of this region.
\end{abstract}

\section{Introduction}

Cephalopods play an important role in the marine ecosystems worldwide, being a major prey of fish, seabirds and marine mammals, but also supporting some fisheries worldwide (Boyle and Rodhouse, 2005; Caddy and Rodhouse, 1998; Clarke, 1996; Piatkowski et al., 2001; Santos et al., 2001). More than 800 cephalopod species have been described worldwide, including demersal and pelagic species, and

\footnotetext{
* Corresponding author.

E-mail address: jqueiros@student.uc.pt (J.P. Queirós).
} 
distributed in all types of environments, from coastal waters to deep-sea regions (Boyle and Rodhouse, 2005; Clarke, 1996; Hoving et al., 2014). Despite this importance, a lot remains to be discovered in terms of the distribution and the ontogenetic dietary shifts of cephalopods, especially for oceanic and deep-sea species (Clarke, 1996; Hoving et al., 2014). This mainly occurs because cephalopods have the ability to avoid scientific nets, with this sampling method being highly inefficient, catching few and mainly small specimens (Boyle and Rodhouse, 2005; Clarke, 1996; Rodhouse, 1990). To overcome this, the stomach content analysis of cephalopod predators has been used throughout the world to study the diversity, distribution and estimate abundances of these organisms (Boyle and Rodhouse, 2005; Cherel, 2020, 2021; Clarke et al., 1993; Dede et al., 2016; Kousteni et al., 2018; Lefkaditou and Poulopoulos, 1998; Potier et al., 2007; Romeo et al., 2012; Santos et al., 2001; Xavier et al., 2014).

The important role of cephalopods in the marine ecosystems has also been recognized in the Southern Ocean, where cephalopods are the main link between lower and higher trophic levels (Cherel, 2020; Xavier et al., 2018). In the Southern Ocean, cephalopods are consumed by top predators such as the elephant seal Mirounga leonina (Rodhouse et al., 1992), the Antarctic toothfish Dissostichus mawsoni (Stevens et al., 2014), the wandering albatross Diomedea exulans (Xavier et al., 2014) and the sperm whale Physeter macrocephalus (Clarke, 1980). Annually, it is estimated that approximately 12.5 to 24 million tonnes of cephalopods are consumed by these predators (Santos et al., 2001). Nevertheless, information on the biogeography and ontogeny of Southern Ocean's cephalopods remains scarce. Previous studies showed that most Southern Ocean squid occupy the pelagic zone whereas most octopuses inhabit benthic environments (Collins and Rodhouse, 2006). Geographically squid distribution can be determined, and sometimes limited, by oceanic fronts (Cherel, 2020). However, several studies confirm the presence of the same species in different water masses (Cherel, 2020; Rodhouse et al., 2014), suggesting that oceanic fronts are not absolute barriers for some squids. Concerning octopuses, the knowledge on their distribution is limited with most of the sampling targeting this group occuring around the Antarctic Peninsula, while the octopod fauna of several regions (e.g. Adélie Land in the D'Urville Sea) remains unknown (Allcock, 2014).

The use of cephalopod predators such as toothfish, sharks, albatrosses, penguins and seals as biological samplers has been used to provide valuable information on the distribution of cephalopods in the Southern Ocean (Reviewed in Cherel, 2020). However, some remote areas, such as the Ross, Amundsen and D'Urville Seas remain particularly poorly studied especially because scientific cruises targeting these organisms in these seas are even more scarce (Griffiths, 2010), and few studies looked to the cephalopod component of predators' diet (Cherel and Kooyman, 1998; Fenaughty et al., 2003; Offredo and Ridoux, 1985; Stevens et al., 2014). One of the cephalopod predators in these regions is the Antarctic toothfish D. mawsoni. Previous studies using different methodologies such as stomach contents, fatty acids and metabarcoding, showed that Antarctic toothfish is a demersal top predator that feeds primarily on fish, but it also preys upon several squids, e.g. Moroteuthopsis longimana and Psychroteuthis glacialis, and octopuses, e.g. Pareledone turqueti and Stauroteuthis gilchristi (Collins et al., 2007; Fenaughty et al., 2003; Jo et al., 2013; Remeslo et al., 2015; Roberts et al., 2011; Stevens et al., 2014; Yoon et al., 2017). The Antarctic toothfish, like its close relative the Patagonian toothfish Dissostichus eleginoides, can be found down to depths of c. 2,200 $\mathrm{m}$ and it is a sedentary species with individuals not moving between areas in a short time period (Hanchet et al, 2008, 2015). Due to such characteristics, both species are useful biological samplers of the areal and depth distributions of bathyal cephalopods (Cherel et al., 2004; Seco et al., 2016; Xavier et al., 2002).

The use of predators as biological samplers mostly relies on the use of cephalopod beaks, which accumulate in the predators' stomachs (Clarke, 1962) and allow the species' identification, as well as the estimation of the cephalopod mass and mantle length using allometric equations (Clarke, 1986; Lu and Ickeringill, 2002; Xavier and Cherel, 2009). Stable isotopic analysis of such beaks are commonly used to study their habitat $\left(\delta^{13} \mathrm{C}\right)$ and trophic ecology $\left(\delta^{15} \mathrm{~N}\right)$ (Cherel and Hobson, 2005). When applied to different parts of the cephalopod beak allows investigating ontogenetic changes, with the tip of the rostrum being a proxy for early life-stages and the end of the hood in upper beaks for the later period of the squid's life (Guerra et al., 2010; Queirós et al., 2018). Combining the cephalopod beak identification with the genetic analysis of unidentifiable flesh fragments from food samples has also the potential to gather useful information on the repartition and trophic relationships of cephalopods (Carreon-Martinez et al., 2011).

The aim of the present study was to describe the geographic and bathymetric distribution of Antarctic cephalopods by using Antarctic toothfish as biological sampler and fisheries bycatch specimens from three locations, i.e. Ross, Amundsen and D'Urville Seas. The identification of the cephalopods found in the stomachs of Antarctic toothfish was achieved by the taxonomic identification of cephalopod beaks and DNA barcoding of cephalopod muscle tissue. Furthermore, using stable isotopic analysis of $\delta^{13} \mathrm{C}$ and $\delta^{15} \mathrm{~N}$ in two sections of the upper beak, we assessed the ontogenetic changes in habitat and trophic ecology of the two most common cephalopod species, Moroteuthopsis longimana and Psychroteuthis glacialis, in the Amundsen and D'Urville Seas.

\section{Material and methods}

\subsection{Data collection}

Loose cephalopod beaks, partially digested specimens and pieces of cephalopod flesh were collected from 1,350 stomachs of Antarctic toothfish caught between December 2016 and February 2017 on board the FV Antarctic Discovery within the CCAMLR (Commission for the Conservation of Antarctic Marine Living Resources) convention area in the Small Scale Research Units: 88.1C (Ross Sea), 88.2H, 88.2F (Amundsen Sea) and 58.4.1G (D'Urville Sea). These capture sites include oceanic seamount $(88.1 \mathrm{C}$ and $88.2 \mathrm{H})$ and slope $(88.2 \mathrm{~F}$ and $58.4 .1 \mathrm{G}$ ) areas at depths between $\sim 650 \mathrm{~m}$ and $\sim 1,900 \mathrm{~m}$. Antarctic toothfish were captured using a longline system baited with the squid Illex argentinus. After hauled the fish were beheaded and gutted by professional fisherman and the stomach was separated from the other viscera. Due to limitations onboard during fishing operations the fish could not be measure before sampling the stomachs. The stomachs were dissected onboard and cephalopod prey items were sorted. All beaks identified from stomachs belonging to Antarctic toothfish captured in the same fishing set were stored together in the same jar. To complement the information on cephalopod species obtained from the stomach contents of Antarctic toothfish, three octopuses accidently caught in the fishing hooks (bycatch specimens) were also included in the study. Cephalopod beaks, partially digested specimens, pieces of cephalopod flesh and bycatch specimens were frozen at $-30{ }^{\circ} \mathrm{C}$ in plastic jars and plastic bags until laboratory analysis.

\subsection{Cephalopod beak identification}

At the laboratory, cephalopod beaks, partially digested specimens, pieces of cephalopod flesh and bycatch specimens were defrosted, and loose beaks preserved in 70\% ethanol. Squid loose beaks were separated into upper and lower beaks and identified to the lowest taxonomic level using a cephalopod beak guide (Xavier and Cherel, 2009) and the NIWA (National Institute for Water and Atmospheric Research, New Zealand) reference collection. Partially digested and bycatch octopuses were identified using specimens from the NIWA invertebrate collection, and their beaks posteriorly removed and preserved in 70\% ethanol. Loose beaks from Antarctic octopuses were not identified because detailed guides are unavailable for these organisms. The lower hood length (LHL) in octopuses, lower rostral length (LRL) and upper hood length (UHL in 
beaks analysed for stable isotopes) in squid were measured using a digital calliper ( $\pm 0.01 \mathrm{~mm}$; Fig. 1). Estimated mass (in g) and mantle length (in $\mathrm{mm}$ ) were calculated using allometric equations ( $\mathrm{Lu}$ and Ickeringill, 2002; Xavier and Cherel, 2009).

\subsection{Genetic analyses}

Fifty-four cephalopod muscle tissue samples were stored in $99 \%$ ethanol and subsequently used for species identification through sequencing of the mitochondrial cytochrome $c$ oxidase subunit I gene (COI) as elective DNA barcoding marker (Hebert et al., 2003). The universal metazoan primer pair LCO1490 and HCO2198, already described as DNA markers for cephalopods (Gebhardt and Knebelsberger, 2015; Queirós et al., 2020; Xavier et al., 2016a), was used as described by Folmer et al. (1994).

About $20 \mathrm{mg}$ of muscle tissue of each specimen was used for total genomic DNA (gDNA) extraction using the CTAB protocol (Borges et al., 2009) with minor modifications. Briefly, tissues were minced with a sterile blade, manually grinded with a plastic mortar in a $1.5 \mathrm{~mL}$ microtube and incubated $30 \mathrm{~min}$ at $60{ }^{\circ} \mathrm{C}$ with agitation in $750 \mu \mathrm{l}$ of pre-heated CTAB extraction buffer (20 mM EDTA, $0.1 \mathrm{M}$ Tris- $\mathrm{HCl} \mathrm{pH}$ 8.0, $1.4 \mathrm{M} \mathrm{NaCl}, 2 \% \mathrm{CTAB}$; and $2 \% \beta$-mercaptoethanol added just before use) until the sample was dissolved. An equal volume of chloroform-isoamylalcohol $(24: 1)$ was added (v/v), and the samples were vortexed and centrifuged for $10 \mathrm{~min}$ at $18000 \times \mathrm{g}$. Then, the organic phase was recovered and resuspended in 0.6 volume of cold isopropanol and left to precipitate at $-20{ }^{\circ} \mathrm{C}$ for $2 \mathrm{~h}$. Samples were then centrifuged for $10 \mathrm{~min}$ at $18000 \times g$ and the resulting pellet was washed once (EtOH 70\%; $10 \mathrm{mM}$ ammonium acetate) and centrifuged at 18 $000 \times g$ for $10 \mathrm{~min}$. Pellets were resuspended in $50 \mu \mathrm{l}$ of milli-Q $\mathrm{H}_{2} \mathrm{O}$. DNA integrity was visualized through gel electrophoresis, while DNA quantity and quality were assessed using ND-1000 UV Spectrophotometer NanoDrop (Thermo Fisher Scientific Inc, USA).

The DNA barcode region $-648 \mathrm{bp}$ from the $5^{\prime}$ end of cytochrome $c$ oxidase subunit 1 (COI)-was amplified in $25 \mu$ l-reactions with the following conditions: 5X PCR buffer (GoTaq ${ }^{\circledR}$ Flexi DNA Polymerase, Promega), $2 \mathrm{mM} \mathrm{MgCl}_{2}, 200 \mathrm{mM}$ of each primer, $200 \mathrm{mM}$ dNTPs, $1.25 \mathrm{U}$ of GoTaq ${ }^{\circledR}$ Flexi DNA Polymerase (Promega), between 25 and $100 \mathrm{ng}$ of gDNA per sample was used as template. The PCR reaction profile was set as follows: $10 \mathrm{~min}$ at $94^{\circ} \mathrm{C}, 30$ cycles of $1 \mathrm{~min}$ at $94^{\circ} \mathrm{C}, 1 \mathrm{~min}$ at $50{ }^{\circ} \mathrm{C}, 3$ min at $72{ }^{\circ} \mathrm{C}$ and a final extension step of $7 \mathrm{~min}$ at $72{ }^{\circ} \mathrm{C}$.

PCR amplified products were purified using the Sureclean plus kit (Bioline) following the manufacturer's instructions. Sanger sequencing of the purified PCR products using the forward and reverse primers was conducted at STAB Vida (Investigação e Serviços em Ciências Biológicas, Lda, Monte da Caparica, Portugal).

DNA sequences were then manually edited using the program BioEdit version 7.2.2 (Hall, 1999) and matched against those held in Barcode of Life Data Systems BOLD (http://www.boldsystems.org/index. php/IDS_OpenIdEngine (Ratnasingham and Hebert, 2007)) and in
NCBI BLASTn (https://blast.ncbi.nlm.nih.gov/Blast.cgi?PROGRAM=bl astn\&PAGE_TYPE=BlastSearch\&LINK_LOC=blasthome, GenBank (Benson et al., 2013)) for species-level identification.

\subsection{Stable isotope analysis}

Ten upper beaks, with similar size, per species and location of the two most common species, $M$. longimana (D’Urville Sea) and $P$. glacialis (Amundsen and D'Urville Seas) were randomly selected. Using stainless scissors, two different regions were sectioned from each beak following Queirós et al. (2019): the tip of the rostrum (R) and the end of the hood (H) (Fig. 1). These sections were cleaned with $80 \%$ ethanol and stored in separate microtubes. Beak samples were dried overnight in an oven at $60{ }^{\circ} \mathrm{C}$ and milled using a mixer mill Retsch ${ }^{\circledR}$ MM400.

Stable isotopic analyses of $\delta^{13} \mathrm{C}$ and $\delta^{15} \mathrm{~N}$ were performed in both beak sections ( $\mathrm{R}$ and $\mathrm{H}$ ). Approximately $0.35 \mathrm{mg}$ of each sample was weighed in a tin capsule using a Mettler Toledo ${ }^{\circledR}$ UMX2 ultramicrobalance. Stable isotope ratios of carbon and nitrogen were measured with an elemental analyser connected on-line to a continuous flow isotope ratio mass spectrometer. Results are presented using $\delta$ notation in parts per mil (\%) as deviation from standards using the equation $\delta \mathrm{X}=\left(\frac{R_{\text {sample }}}{R_{\text {standard }}}-1\right) \times 1000$

where $\mathrm{X}$ represents ${ }^{13} \mathrm{C}$ or ${ }^{15} \mathrm{~N}$ and $\mathrm{R}$ the ratios ${ }^{13} \mathrm{C} /{ }^{12} \mathrm{C}$ or ${ }^{15} \mathrm{~N} /{ }^{14} \mathrm{~N}$. $\mathrm{R}_{\text {standard }}$ is the reference standard value of Vienna PeeDee Belemnite (VPDB) and Atmospheric Nitrogen (AIR) for carbon and nitrogen, respectively. As chitin is depleted in ${ }^{15} \mathrm{~N}$, but not in ${ }^{13} \mathrm{C}$, in relation to proteins (Cherel et al., 2009), and the ratio between chitin and protein concentrations vary along the beak (Miserez et al., 2008), $\delta^{15} \mathrm{~N}$ values can be lowered in beak regions with higher concentrations of chitin (Cherel et al., 2009). To compare the relative chitin content between beak sections of the same species, C:N mass ratios were calculated. Internal machine errors were systematically measured using acetanilide (STD: Thermo Scientific ${ }^{\circledR}$; PN 33836700 ), indicating an error of $<0.3 \%$ for $\delta^{13} \mathrm{C}$ and $<0.1 \%$ for $\delta^{15} \mathrm{~N}$.

\subsection{Statistical analyses}

A $\chi^{2}$-test was used to analyse the proportion of identified taxa in each sampling area, with the $p$-value being calculated using a statistical online software (http://www.socscistatistics.com/pvalues/chidistribution. aspx). To test if larger individuals are found in deeper waters, Spearman correlation tests were performed between the average depth of the longlines and the lower rostral length of squid ( $P$. glacialis and $M$. longimana) or the lower hood length of octopuses (Megaleledone setebos and Stauroteuthis gilchristi). These correlations were made on species for which more than ten lower beaks were identified and preceded by a Shapiro-Wilk normality test. The normality and homogeneity of $\delta^{13} \mathrm{C}$ and $\delta^{15} \mathrm{~N}$ values and C:N mass ratios of each population in both
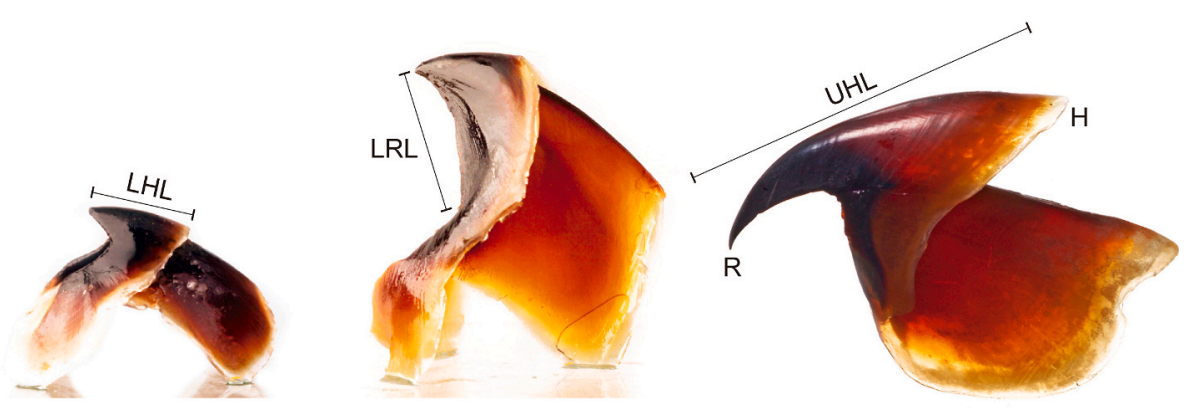

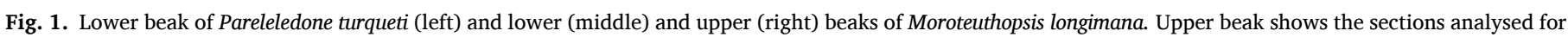

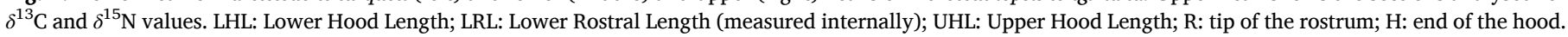
Photos adapted from Xavier and Cherel (2009). 


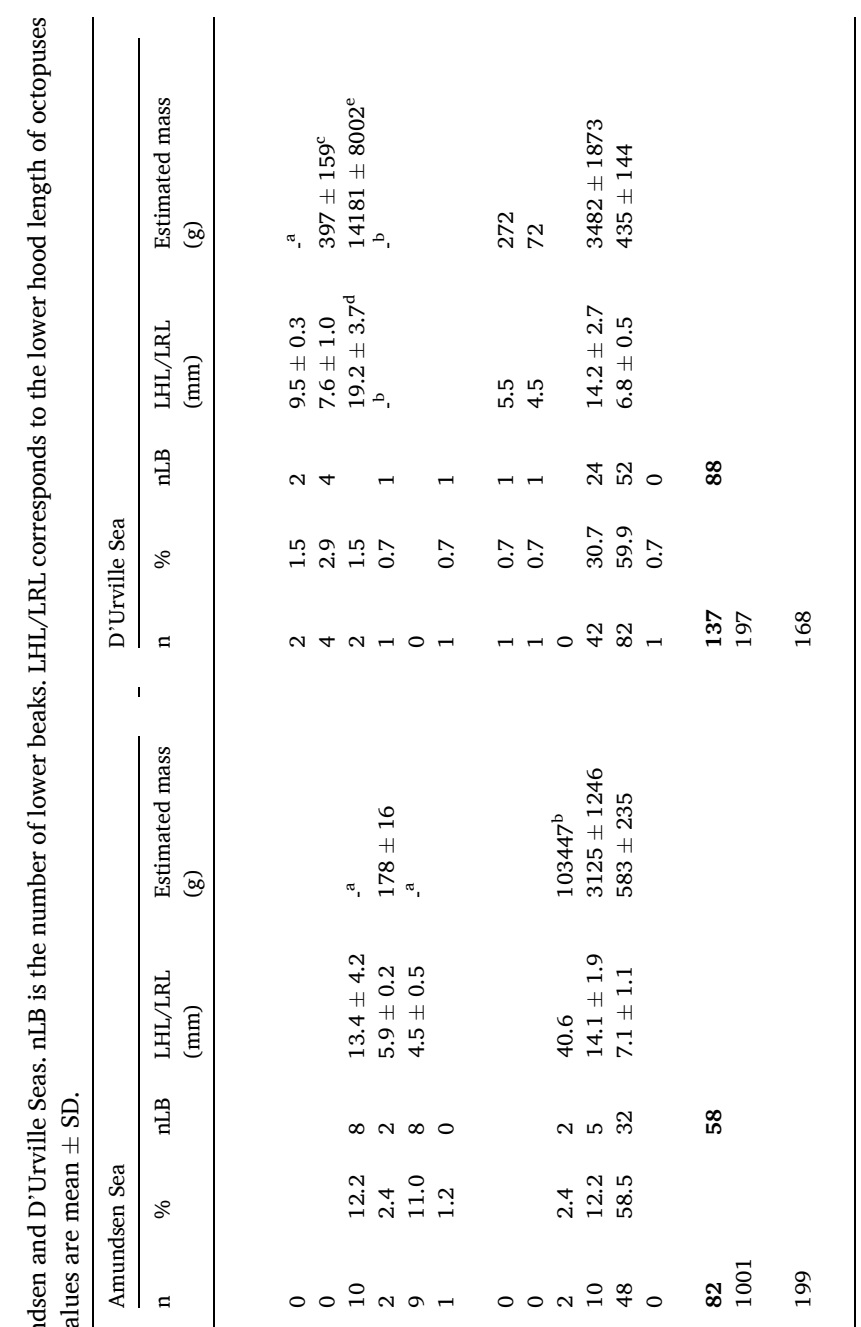

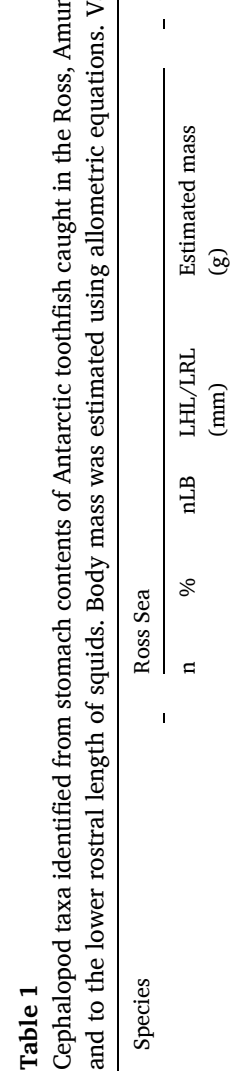

beak sections was tested using a Shapiro-Wilk test and a Bartletts' test, respectively. Statistically significant differences between the $\delta^{13} \mathrm{C}$ and $\delta^{15} \mathrm{~N}$ values and C:N mass ratios of the sections of each beak were tested using a Wilcoxon-test ( $P$. glacialis in the Amundsen Sea) and a paired $t$ test (M. longimana and P. glacialis in the D'Urville Sea). Using $\delta^{15} \mathrm{~N}$ as a proxy of cephalopod trophic position, changes in the trophic position between life stages were calculated considering an increase of $\delta^{15} \mathrm{~N}$ values of $3.3 \%$ per trophic level (Hobson and Cherel, 2006). These tests were performed in GraphPad Prism ${ }^{\circledR}$ v6.01 using $\alpha=0.05$ and images were prepared using Adobe Illustrator ${ }^{\circledR}$ CC 2015 . Given values are Mean \pm SD.

\section{Results}

\subsection{Cephalopod component of the diet of Antarctic toothfish}

A total of 232 cephalopod beaks were sorted from 1,350 stomach contents (including 86 beaks from partially digested cephalopod specimens and from three octopuses caught on fishing hooks). The cephalopods beaks were divided into 157 lower (67.7\%) and 75 upper (32.3\%) beaks corresponding to ten cephalopod taxa (Table 1). Based on macroscopic examination of cephalopod beaks and DNA barcoding analysis, a total of eight, six and four taxa of cephalopods were identified in the D'Urville, the Amundsen and the Ross Seas, respectively. The species identified by DNA barcoding were already identified by macroscopic examination of the beaks.

Ten out of 54 muscle tissue samples were successfully sequenced for the COI gene region and identified. Two specimens of $M$. longimana and three out of eight specimens of $M$. hamiltoni were identified genetically in the stomach contents of Antarctic toothfish captured in the Amundsen Sea. (Table 2). The remaining five specimens of $M$. hamiltoni were obtained from stomachs of Antarctic toothfish caught in the D'Urville Sea (Table 2). Nucleotide sequences were submitted to GenBank and have accession numbers MT358595 - MT358604.

The oceanic squid $P$. glacialis was the most abundant species in the Antarctic toothfish stomachs in the Amundsen (58.5\%; $\chi^{2}{ }_{5}=157.3, p<$ 0.001 ) and the D'Urville (59.9\%; $\chi_{8}^{2}=414.4, p<0.001$ ) Seas, whereas the octopus, $S$. gilchristi was the most abundant species in the Ross Sea $\left(35.7 \% ; \chi^{2}{ }_{3}=8.10, p=0.044\right)$ (Table 1$)$.

\subsection{Bathymetric distribution of cephalopods based on Antarctic toothfish diet}

Cephalopods were recovered from Antarctic toothfish caught between 700 and 1,900 m, with the highest number of beaks being found between 1,300 and $1,500 \mathrm{~m}$ of depth (Fig. 2). P. glacialis was the only cephalopod found in the stomach of the Antarctic toothfish at all depths, and the only found deeper than $1,800 \mathrm{~m}$ (Appendix 1). M. setebos was the only species presenting a discontinuous depth distribution with two beaks identified between 700 and $900 \mathrm{~m}$ (two bycatch individuals) and the other ten beaks from Antarctic toothfish captured between 1,300 and 1,800 m deep (Fig. 2, Appendix 1). Significant correlations between depth and lower rostral length were found for both P. glacialis $(\mathrm{n}=80, r=$ $0.420, p<0.001)$ and $M$. longimana $(\mathrm{n}=28, r=0.399, p=0.036)$. No significant correlations were obtained between the depth and lower hood length in the octopuses $M$. setebos $(\mathrm{n}=12, p=0.058)$ and $S$. gilchristi $(\mathrm{n}=14, p=0.398)$.

\subsection{Upper beak $\delta^{13} C$ and $\delta^{15} N$ values of $M$. longimana and P. glacialis}

The smallest $\delta^{13} \mathrm{C}$ value (-26.0\%) was measured in the end of the hood of $P$. glacialis, whereas the highest $\delta^{13} \mathrm{C}$ value $(-21.5 \%$ ) was in the end of the hood of M. longimana, both from the D'Urville Sea (Table 1). Significant differences in $\delta^{13} \mathrm{C}$ values were found between the tip of the rostrum and the end of the hood for $P$. glacialis from the Amundsen Sea (Wilcoxon test, $\mathrm{W}=21.0, p=0.031$ ) (Fig. 3). Conversely, no significant 
Table 2

List of DNA-barcoded specimens and their corresponding GenBank accession numbers.

\begin{tabular}{|c|c|c|c|c|c|c|}
\hline Seq. No. & Tissue & Location & BLAST annotation & Database & e-value/Similarity & GenBank Acc. No. \\
\hline \multirow[t]{2}{*}{1} & \multirow[t]{2}{*}{ Tentacle } & \multirow[t]{2}{*}{ D'Urville Sea (58.4.1G) } & \multirow[t]{2}{*}{ Mesonychoteuthis hamiltoni } & NCBIn & 0.0 & \multirow[t]{2}{*}{ MT358595 } \\
\hline & & & & BOLD & $100 \%$ & \\
\hline \multirow[t]{2}{*}{2} & \multirow[t]{2}{*}{ Tentacle } & \multirow[t]{2}{*}{ Amundsen Sea (88.2F) } & \multirow[t]{2}{*}{ Moroteuthopsis longimana } & NCBIn & 0.0 & \multirow[t]{2}{*}{ MT358596 } \\
\hline & & & & BOLD & $100 \%$ & \\
\hline \multirow[t]{2}{*}{3} & \multirow[t]{2}{*}{ Mantle } & \multirow[t]{2}{*}{ Amundsen Sea (88.2F) } & \multirow[t]{2}{*}{ Mesonychoteuthis hamiltoni } & NCBIn & 0.0 & \multirow[t]{2}{*}{ MT358597 } \\
\hline & & & & BOLD & $100 \%$ & \\
\hline \multirow[t]{2}{*}{4} & \multirow[t]{2}{*}{ Tentacle } & \multirow[t]{2}{*}{ D'Urville Sea (58.4.1G) } & \multirow[t]{2}{*}{ Mesonychoteuthis hamiltoni } & NCBIn & 0.0 & \multirow[t]{2}{*}{ MT358598 } \\
\hline & & & & BOLD & $100 \%$ & \\
\hline \multirow[t]{2}{*}{5} & \multirow{2}{*}{ Tentacle } & \multirow{2}{*}{ D’Urville Sea (58.4.1G) } & \multirow{2}{*}{ Mesonychoteuthis hamiltoni } & NCBIn & 0.0 & \multirow{2}{*}{ MT358599 } \\
\hline & & & & BOLD & $100 \%$ & \\
\hline \multirow[t]{2}{*}{6} & \multirow[t]{2}{*}{ Tentacle } & \multirow[t]{2}{*}{ Amundsen Sea (88.2F) } & \multirow[t]{2}{*}{ Mesonychoteuthis hamiltoni } & NCBIn & 0.0 & \multirow[t]{2}{*}{ MT358600 } \\
\hline & & & & BOLD & $100 \%$ & \\
\hline \multirow[t]{2}{*}{7} & \multirow[t]{2}{*}{ Tentacle } & \multirow[t]{2}{*}{ Amundsen Sea (88.2F) } & \multirow[t]{2}{*}{ Mesonychoteuthis hamiltoni } & NCBIn & 0.0 & \multirow[t]{2}{*}{ MT358601 } \\
\hline & & & & BOLD & $100 \%$ & \\
\hline 8 & Mantle & D'Urville Sea (58.4.1G) & Mesonychoteuthis hamiltoni & NCBIn & 0.0 & MT358602 \\
\hline & & & & BOLD & $100 \%$ & \\
\hline 9 & Mantle & D'Urville Sea (58.4.1G) & Mesonychoteuthis hamiltoni & NCBIn & 0.0 & MT358603 \\
\hline & & & & BOLD & $100 \%$ & \\
\hline 10 & Tentacle & Amundsen Sea (88.2F) & Moroteuthopsis longimana & NCBIn & 0.0 & MT358604 \\
\hline & & & & BOLD & $100 \%$ & \\
\hline
\end{tabular}

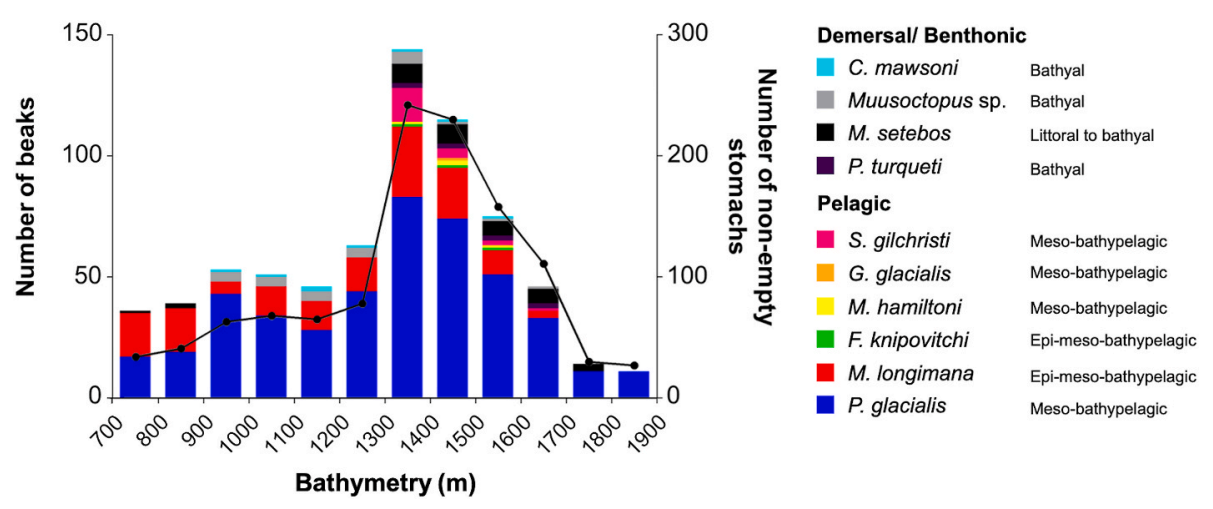

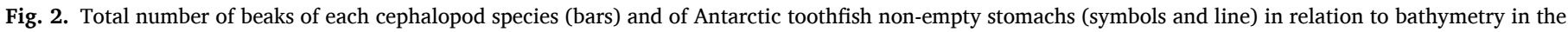
Ross, Amundsen and D'Urville Seas combined. The legend includes the known vertical distribution of the species.

differences in $\delta^{13} \mathrm{C}$ values were found between beak sections in $M$. longimana (paired $t$-test, $\mathrm{t}_{6}=0.28, p=0.788$ ) and $P$. glacialis (paired $t$ test, $\mathrm{t}_{7}=0.514, p=0.6232$ ) from the D'Urville Sea (Table 3, Fig. 3).

Regarding $\delta^{15} \mathrm{~N}$ values, the tip of the rostrum of $M$. longimana from the D'Urville Sea $(+3.0 \%$ o) and the end of the hood of $P$. glacialis from Amundsen Sea $(+11.3 \%)$ had the lowest and highest values, respectively (Table 1). Significant differences in $\delta^{15} \mathrm{~N}$ values were found between the tip of rostrum and the end of the hood of the two species in both studied seas (paired $t$-test: $M$. longimana in D'Urville Sea, $\mathrm{t}_{6}=8.20$, $p<0.001 ; P$. glacialis in D'Urville Sea, $\mathrm{t}_{7}=2.65, p=0.033$; Wilcoxon test: P. glacialis in Amundsen Sea, $\mathrm{W}=21.0, p=0.031$; Table 3, Fig. 3).

Concerning C:N mass ratios, both squid species in the Amundsen and D'Urville Seas presented significant differences between beak sections (paired $t$-test: $M$. longimana in D'Urville Sea, $\mathrm{t}_{6}=14.2, p<0.001$; $P$. glacialis in D'Urville Sea, $\mathrm{t}_{7}=3.53, p=0.009$; Wilcoxon test: $P$. glacialis in Amundsen Sea, $\mathrm{W}=-21.0, p=0.031$ ), with the tip of the rostrum showing higher C:N mass ratios than the end of the hood (Table 3 ).

\section{Discussion}

Ten cephalopod taxa, four demersal/benthic octopuses (Cirroctopus mawsoni, Pareledone turqueti, M. setebos, Muusoctopus (formerly Benthoctopus sp.), one pelagic octopus (S. gilchristi) and fivepelagic squids (Galiteuthis glacialis, Filippovia knipovitchi, M. hamiltoni, M. longimana and $P$. glacialis) were identified in this study by macroscopical identification of beaks and by DNA barcoding of cephalopod muscle tissue found in the stomachs of Antarctic toothfish. Using the depth of capture of Antarctic toothfish we were able to determine that five taxa (C. mawsoni, Muusoctopus sp., $M$. setebos, $P$. turqueti, and $P$. glacialis) inhabit deeper waters than previously known. Stable isotopic analysis of $\delta^{15} \mathrm{~N}$ and $\delta^{13} \mathrm{C}$ of two beak sections of $P$. glacialis from Amundsen and D'Urville Seas and $M$. longimana from the D'Urville Sea confirmed also that both species increase the trophic position with growth, but do not overlap in their foraging habitat.

\subsection{Cephalopod taxa in the diet of Antarctic toothfish in the Ross, Amundsen and D'Urville Seas}

Our study provides new information on the biodiversity and biogeography of cephalopods of the Ross, Amundsen and D'Urville Seas. These regions are poorly documented with few studies describing the cephalopod species present in the diet of predators, e.g. Emperor penguins Aptenodytes forsteri and Antarctic toothfish (Cherel and Kooyman, 1998; Fenaughty et al., 2003; Ridoux and Offredo, 1989; Stevens et al., 2014). However, Garcia (2010) and Thompson et al. (2012) made the first detailed studies of cephalopods in the Ross Sea by combining data from research voyages (both studies) and analysis of the diet of predators (Thompson et al., 2012). The ten cephalopod taxa identified in the present work have already been reported in the diet of Antarctic toothfish from the Ross Sea (Stevens et al., 2014; Thompson et al., 2012). This data complements information from biological research surveys (e.g. M. hamiltoni: reviewed in Rosa et al. (2017); P. turqueti: 

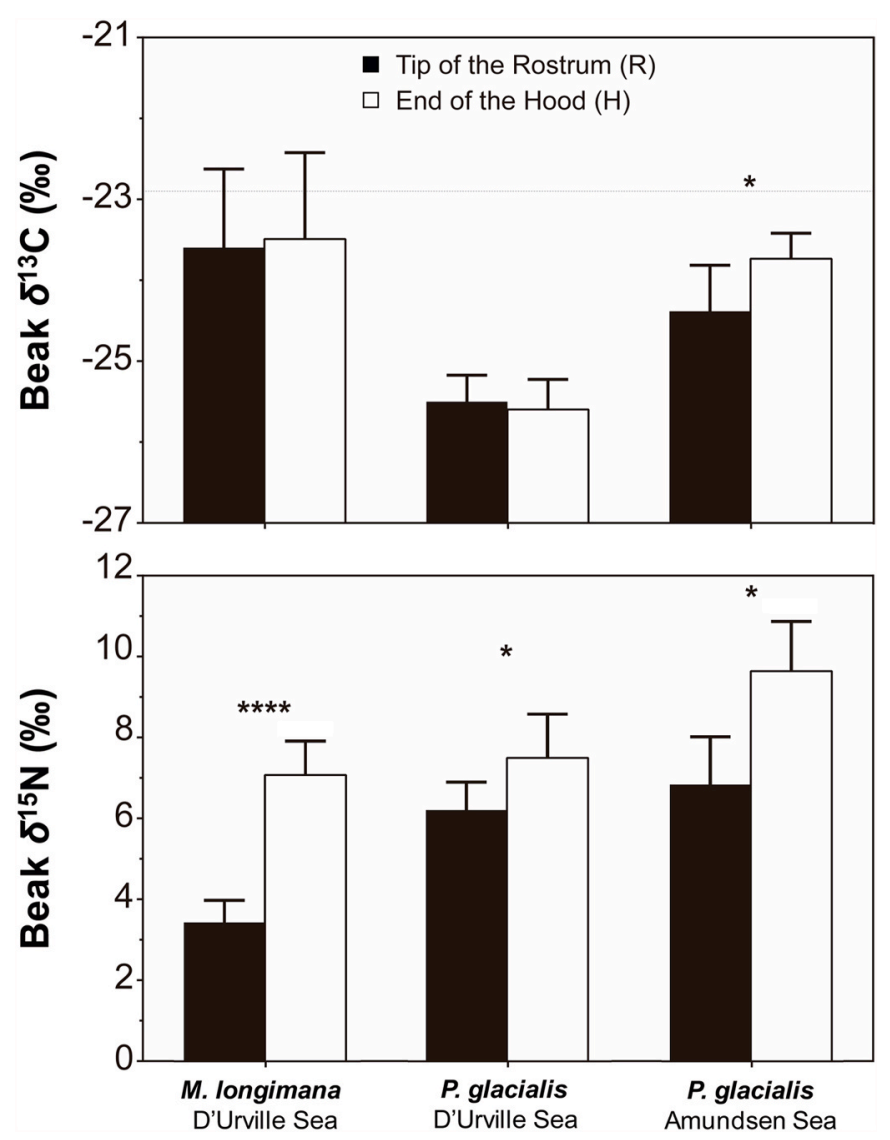

Fig. 3. Stable isotope values in each section of upper beaks of Moroteuthopsis longimana and Psychroteuthis glacialis. Grey dashed line is the estimated isotopic value for the Antarctic Polar Front based on wandering albatross Diomedea exulans plasma (Jaeger et al., 2010). Values are mean \pm SD $(n=10)$. * $p$-value $<0.05 ; * * * * p$-value $<0.001$.

Strugnell et al. (2012)) and from other predators (e.g. Emperor penguin: Cherel and Kooyman (1998)). To our knowledge, this is the first study on the cephalopods from the Amundsen and D'Urville Seas using the Antarctic toothfish as a biological sampler.

The identification of ten flesh samples proved that DNA barcoding can be a potential tool to identify Southern Ocean squid species from the contents of predators' stomachs. However, a main obstacle to a successful barcode can be the advanced state of digestion of the prey (Buckland et al., 2017; Rosel and Kocher, 2002), because gDNA can be too fragmented (Blankenship and Yayanos, 2005; Moran et al., 2015; Smith et al., 2005). The successful identification of ten samples from stomachs of a deep-sea fish, suggest that this technique might be a promising tool to study the bathyal, abyssal and hadal cephalopods which might not float after death (Hoving et al., 2017). Moreover, as marine fish tend to regurgitate (Bowman, 1986), especially deep-sea species during their ascent to the surface (Drazen and Sutton, 2017; Pilling et al., 2001), the identification of any type and amount of sample assumes a major importance in this research area (Gutt et al., 2021). Metabarcoding of stomach contents, regardless of their digestive stage, has been recently applied (e.g. Barbato et al., 2019), and this technology could be considered in future studies as an optional approach for an overall assessment of taxonomic composition and diversity of Southern Ocean cephalopods.

From the ten identified taxa, only the octopuses $C$. mawsoni and S. gilchristi are not known to have a circumpolar distribution (Allcock, 2014; Rodhouse et al., 2014). However, as C. antarctica (known to occur in South Shetland Islands) and C. glacialis (known to occur in the Weddell Sea and Antarctic Peninsula) might be synonymous of $C$. mawsoni, it has been hypothesised that $C$. mawsoni also have a circumpolar distribution (Allcock, 2014). Regarding S. gilchristi, this species is distributed throughout the South Atlantic, with only one record from the Ross Sea (Allcock, 2014). The presence of several beaks in the stomachs of Antarctic toothfish from the Ross and Amundsen Seas in our study (Table 1) shows that $S$. gilchristi also inhabits the Pacific sector of the Southern Ocean.

Although most of the identified taxa in our study have a circumpolar distribution (Allcock, 2014; Cherel, 2020; Rodhouse et al., 2014), only $P$. turqueti and $M$. longimana were found in the diet of Antarctic toothfish in the Ross, Amundsen and D'Urville Seas (Table 1). In the Amundsen Sea, demersal/benthic octopuses (e.g. M. setebos), pelagic octopuses (e. g. S. gilchristi) and pelagic squids (e.g. M. longimana) were found in Antarctic toothfish stomachs, reflecting the sampling from both seamount and slope areas. This presence/absence pattern is probably due to differences between the topography of the sampling sites (i.e. slope areas in the Amundsen and D'Urville Seas and oceanic seamount areas in Ross and Amundsen Seas). A previous study, that modelled the biogeography of Southern Ocean squid, hypothesised that depth and topography might influence the distribution of squids (Xavier et al., 2016b). Our study hypothesises that, at least topography, also influences the distribution of Antarctic octopuses.

Previous studies identified the cephalopod fauna of the different Southern Ocean regions using both Antarctic and Patagonian toothfish as biological samplers. Some of these found a higher number of taxa than those identified here; 29 and 25 species were identified in Crozet and Kerguelen Islands (Cherel et al., 2004), respectively, and 16 in South Georgia (Xavier et al., 2002) and Macquarie Islands (Goldsworthy et al., 2002). In contrast, only seven, four and three species were found in South Sandwich Islands (Seco et al., 2016), Argentinian continental shelf/slope (García de la Rosa et al., 1997) and Falkland Islands (Troccoli et al., 2020). These differences might suggest a circumpolar regional variation in the abundance of cephalopod species in the diet of toothfish species but also a latitudinal variability, with sub-Antarctic archipelagos

Table 3

Stable isotope values of upper beaks of Moroteuthopsis longimana and Psychroteuthis glacialis from the Amundsen and D'Urville Seas. UHL: Upper Hood Length; R: tip of the rostrum; H: end of the hood. Values are mean \pm SD.

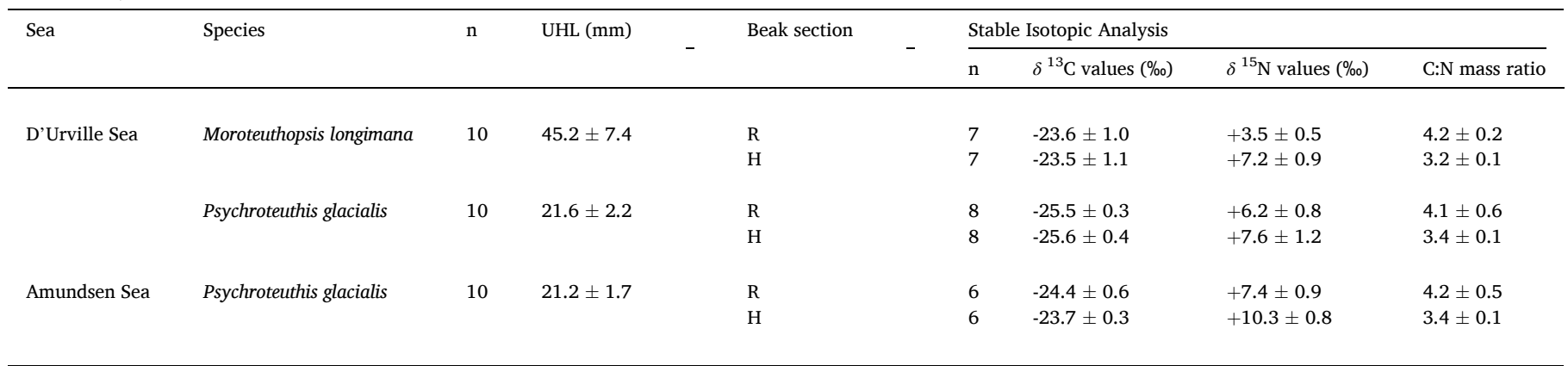


presenting a larger number of cephalopod species than slope and oceanic waters south of Antarctic Polar Front (this study; Cherel, 2020). Yet, toothfish inhabiting Antarctic waters present a higher number of cephalopod species in their diet than those from areas in the Patagonian shelf (García de la Rosa et al., 1997; Troccoli et al., 2020). However, we cannot exclude the possibility that such differences are related to the sampling effort, i.e. the number of stomachs analysed. Furthermore, it can also be related with the capture depth of toothfish, the topography of the region (shelf, slope or seamount), and to specific ecological differences between toothfish populations.

\subsection{Bathymetric distribution of cephalopods in the Ross, Amundsen and} D'Urville Seas

This study provided new insights into the bathymetric distribution of Southern Ocean cephalopod taxa. Our results suggest that $C$. mawsoni, Muusoctopus sp., M. setebos, $P$. turqueti, and P. glacialis can inhabit deeper waters than previously known, yet within expected depth range of the species, i.e. in the meso-bathypelagic zone (Table 4). Several cephalopod species tend to present an ontogenetic descent to deeper waters (Hunt and Seibel, 2000), including P. glacialis and M. longimana (reviewed in Xavier and Croxall, 2007) and M. setebos (Queirós et al., 2020). As Antarctic toothfish tend to feed in larger cephalopods than other predators and those captured by scientific nets (Cherel, 2020), the presence of these species in deeper waters than previous known is not surprising. This ontogenetic descent is supported by the correlation found for $P$. glacialis and $M$. longimana between depth and the beak size. Nevertheless, such correlation was not found for M. longimana in previous studies (Seco et al., 2016). No significant correlation between depth and beak size occurred for both $M$. setebos and S. gilchristi. This contrast with a previous study in $M$. setebos that found a significant correlation between the depth of capture and the mantle length of captured individuals (Queirós et al., 2020).

The highest number of cephalopods identified between 1,300 and $1,500 \mathrm{~m}$ is similar to a previous study performed at South Sandwich Islands using both Antarctic and Patagonian toothfish as biological samplers (Seco et al., 2016). However, it contrasts with the results obtained by Xavier et al. (2002) in South Georgia. This suggests that cephalopods in our study area are an important prey to the Antarctic toothfish in the bathyal area (from 1,000 to 4,000 m deep) of the ocean. Furthermore, it supports the current knowledge in the vertical distribution of Southern Ocean squids (Cherel, 2020) and octopuses (Allcock, 2014; Strugnell et al., 2011). Nevertheless, due to the relationship between the number of beaks and non-empty stomachs, the higher number of beaks identified at these depths might not be related to a higher abundance of cephalopods, but to a larger sampling effort.

\subsection{Ontogenetic changes in habitat and trophic level of $M$. longimana and P. glacialis}

$\delta^{13} \mathrm{C}$ values are relatively stable through the food web and vary with waters masses, being used as a proxy for predators' foraging habitat (Cherel and Hobson, 2007). In the Southern Ocean these values present a latitudinal gradient with southern waters being impoverished in ${ }^{13} \mathrm{C}$ (Brault et al., 2018; Jaeger et al., 2010). Such gradient allows the study of the distribution of $M$. longimana in the D'Urville Sea and of $P$. glacialis in the Amundsen and D'Urville Seas. The lowest $\delta^{13} \mathrm{C}$ values found in $P$. glacialis from the D'Urville Sea suggest that these individuals inhabit more southern areas than both $P$. glacialis and M. longimana from the Amundsen and D'Urville Seas, respectively. In contrast, our study showed that $M$. longimana may migrate from the Polar Frontal Zone, with individuals having $\delta^{13} \mathrm{C}$ values above $-22.9 \%$ (the estimated value for the Antarctic Polar Front (Jaeger et al., 2010)). This confirms the presence of $M$. longimana in northern/warmer waters, as already demonstrated by its presence in the diet of predators (e.g. King penguins Aptenodytes patagonicus and Patagonian toothfish from the sub-Antarctic
Table 4

Comparison of the known depth distribution of cephalopods with results of this study. $\rightarrow$ the depth obtained in this study is within the previous depth limits; $\uparrow$ this study increased the know depth distribution.

\begin{tabular}{|c|c|c|c|c|}
\hline Species & $\begin{array}{l}\text { This study } \\
\text { Depth } \\
\text { Distribution }\end{array}$ & $\begin{array}{l}\text { Known } \\
\text { Vertical } \\
\text { Depth } \\
\text { Distribution }\end{array}$ & $\begin{array}{l}\text { Knowledge } \\
\text { Depth } \\
\text { Distribution }\end{array}$ & Source \\
\hline $\begin{array}{l}\text { Cirroctopus } \\
\text { mawsoni }\end{array}$ & 900 to 1600 & 333 to 940 & $\uparrow$ & $\begin{array}{l}\text { (Allcock, } \\
\text { 2014; Collins } \\
\text { and } \\
\text { Villanueva, } \\
\text { 2006; } \\
\text { Vecchione } \\
\text { et al., 1998) }\end{array}$ \\
\hline Muusoctopus sp. & 900 to 1700 & 250 to 1491 & $\uparrow$ & $\begin{array}{l}\text { (Strugnell } \\
\text { et al., 2011; } \\
\text { Vecchione } \\
\text { et al., 2009) }\end{array}$ \\
\hline $\begin{array}{l}\text { Megaleledone } \\
\text { setebos }\end{array}$ & 700 to 1800 & 0 to 930 & $\uparrow$ & $\begin{array}{l}\text { (Allcock, } \\
2014 ; \\
\text { Allcock et al., } \\
2003 \text {; } \\
\text { Schwarz } \\
\text { et al., 2019) }\end{array}$ \\
\hline $\begin{array}{l}\text { Pareledone } \\
\text { turqueti }\end{array}$ & $\begin{array}{l}1300 \text { to } \\
1700\end{array}$ & 70 to 1200 & $\uparrow$ & $\begin{array}{l}\text { (Collins et al., } \\
\text { 2004; Matias } \\
\text { et al., 2019; } \\
\text { Schwarz } \\
\text { et al., 2019; } \\
\text { Strugnell et } \\
\text { al, 2008, } \\
\text { 2012, 2017; } \\
\text { Xavier et al., } \\
\text { 2002) }\end{array}$ \\
\hline $\begin{array}{l}\text { Stauroteuthis } \\
\text { gilchristi }\end{array}$ & $\begin{array}{l}1300 \text { to } \\
1700\end{array}$ & 700 to 3000 & $\rightarrow$ & $\begin{array}{l}\text { (Allcock, } \\
\text { 2014; Collins } \\
\text { et al., 2004) }\end{array}$ \\
\hline $\begin{array}{l}\text { Filippovia } \\
\qquad \text { knipovitchi }\end{array}$ & $\begin{array}{l}1300 \text { to } \\
1600\end{array}$ & 0 to 1700 & $\rightarrow$ & $\begin{array}{l}\text { (Collins et al., } \\
\text { 2004; } \\
\text { Rodhouse } \\
\text { et al., 1996; } \\
\text { Seco et al., } \\
2016 \text { ) }\end{array}$ \\
\hline $\begin{array}{l}\text { Galiteuthis } \\
\text { glacialis }\end{array}$ & $\begin{array}{l}1400 \text { to } \\
1500\end{array}$ & 200 to 1700 & $\rightarrow$ & $\begin{array}{l}\text { (Filippova } \\
\text { and } \\
\text { Pakhomov, } \\
\text { 1994; } \\
\text { Rodhouse } \\
\text { et al., 1996; } \\
\text { Rodhouse } \\
\text { and Clarke, } \\
\text { 1986; Seco } \\
\text { et al., 2016; } \\
\text { Xavier et al., } \\
\text { 2002) }\end{array}$ \\
\hline $\begin{array}{l}\text { Mesonychoteuthis } \\
\text { hamiltoni }\end{array}$ & $\begin{array}{l}1300 \text { to } \\
1600\end{array}$ & $\begin{array}{l}300 \text { to } \\
\sim 2500\end{array}$ & $\rightarrow$ & $\begin{array}{l}\text { (Filippova } \\
\text { and } \\
\text { Pakhomov, } \\
\text { 1994; Rosa } \\
\text { et al., 2017; } \\
\text { Seco et al., } \\
\text { 2016; Xavier } \\
\text { et al., 2002) }\end{array}$ \\
\hline $\begin{array}{l}\text { Moroteuthopsis } \\
\text { longimana }\end{array}$ & 700 to 1700 & 0 to 1700 & $\rightarrow$ & $\begin{array}{l}\text { (Collins et al., } \\
\text { 2004; Seco } \\
\text { et al., 2016; } \\
\text { Xavier et al., } \\
\text { 2002) }\end{array}$ \\
\hline $\begin{array}{l}\text { Psychroteuthis } \\
\quad \text { glacialis }\end{array}$ & 700 to 1900 & 100 to 1500 & $\uparrow$ & $\begin{array}{l}\text { (Collins et al., } \\
\text { 2004; } \\
\text { Filippova and } \\
\text { Pakhomov, } \\
\text { 1994; Seco } \\
\text { et al., 2016) }\end{array}$ \\
\hline
\end{tabular}


Crozet and Kerguelen Islands (Cherel et al., 2004; Cherel and Weimerskirch, 1999)).

The stable isotope analysis in the two sections of upper beak unraveled habitat changes between early and more advanced life-stages (Guerra et al., 2010; Queirós et al., 2018). The significantly higher $\delta^{13} \mathrm{C}$ values in the end of the hood of $P$. glacialis upper beaks from the Amundsen Sea suggest a northwards movement throughout the life of the individuals. In both life-periods, $\delta^{13} \mathrm{C}$ values show that $M$. longimana inhabit more northern areas than $P$. glacialis, suggesting an absence of habitat overlap between both species. $P$. glacialis in the D'Urville Sea presented similar $\delta^{13} \mathrm{C}$ values for both life-stages, suggesting that both juveniles and adults remained in the same habitat. This is in agreement with the capture of $P$. glacialis of different sizes in the same trawls (Filippova, 1972; Lu and Williams, 1994a). Complementing the presence of juveniles of $M$. longimana in sub-Antarctic waters from the Indian Sector (Cherel and Hobson, 2005; Cherel and Weimerskirch, 1999), our results support that Antarctic waters are important areas for the growth of $M$. longimana juveniles.

In contrast to $\delta^{13} \mathrm{C}$ values, $\delta^{15} \mathrm{~N}$ values are not stable through the food web, with predators being ${ }^{15} \mathrm{~N}$ enriched in relation to their prey (McCutchan et al., 2003; Peterson and Fry, 1987). Therefore, $\delta^{15} \mathrm{~N}$ values are used to study the trophic ecology of the organisms (Peterson and Fry, 1987). As expected, individuals had significant higher $\delta^{15} \mathrm{~N}$ values in the end of the hood than in the rostrum, which shows an increase in the trophic position throughout the life of squids. The largest increase of $\delta^{15} \mathrm{~N}$ value was found in upper beaks of $M$. longimana from the D'Urville Sea and reflects an increase of $\sim 1.1$ trophic level, whereas $P$. glacialis showed an increase of $\sim 0.9$ and $\sim 0.4$ trophic level, in the Amundsen and D'Urville Seas, respectively. This trophic shift is well-documented for $P$. glacialis and it is related to a change from zooplankton and small fish (as juveniles) to larger fish and squid (as adults) (Kear, 1992; Lu and Williams, 1994a). Nevertheless, the smaller increase in P. glacialis' $\delta^{15} \mathrm{~N}$ values from D'Urville Sea may reflect a more varied diet in these smaller individuals or a feeding on smaller prey as adults; or a combination of both, which is the most likely explanation. Some studies analysed stomach contents of $M$. longimana and suggested a diet change from zooplankton to fish/squid as they grow (Lu and Williams, 1994b; Nemoto et al., 1988). Previous stable isotope analyses in beaks showed similar results (Cherel and Hobson, 2005; Queirós et al, 2018, 2021; Seco et al., 2016). An ontogenetic trophic shift is also well-documented for other Southern Ocean species, e.g. Muusoctopus thielei, Moroteuthopsisingens and I. argentinus (Cherel and Hobson, 2005; Collins and Rodhouse, 2006; Queirós et al., 2019; Rodhouse, 2013), and in squids elsewhere (Guerra et al., 2010; Hoving et al., 2014; Rodhouse and Nigmatullin, 1996).

Higher C:N mass ratios in the tip of the rostrum of M. longimana and $P$. glacialis in both seas suggest that $\delta^{15} \mathrm{~N}$ values are lowered (i.e. $\delta^{15} \mathrm{~N}$ values obtained are lower than supposed due to the higher amount of chitin in this beak section (Cherel et al., 2009; Miserez et al., 2008)). However, the tip of the rostrum is composed by a mixture of old and new beak material that might increase the $\delta^{15} \mathrm{~N}$ values expected for the early stage of squid's life (Queirós et al., 2018). This balance between higher $\mathrm{C}: \mathrm{N}$ mass ratio (decrease) and new beak material (increase) might suggest that $\delta^{15} \mathrm{~N}$ values in the tip of the rostrum of all individuals is not higher nor lower than supposed. This indicate that the trophic increases observed in our results are realistic and that $M$. longimana from D'Urville Sea and $P$. glacialis from Amundsen Sea increase approximately one trophic level from juvenile to adult and $P$. glacialis from D'Urville Sea only half a trophic level.

\section{Conclusions}

This was the first study to describe the bathyal cephalopod fauna of the Amundsen and D'Urville Seas using the Antarctic toothfish as a biological sampler. Furthermore, it also added new knowledge for the Ross Sea teuthofauna. Ten different octopus and squid taxa were identified, showing a circumpolar distribution except for $S$. gilchristi. Furthermore, we showed that C. mawsoni, Muusoctopus sp., M. setebos, $P$. turqueti, and $P$. glacialis inhabit deeper waters than previously known. Applying a stable isotope analyses in two beak regions of the two most abundant species, $P$. glacialis and M. longimana, in the Amundsen and D'Urville Seas, we showed that both species increase their trophic level between life-stages, and also that, whether they are juveniles or adults, the foraging habitat of both species do not overlap. The identification of some species using DNA barcoding in flesh tissue from the stomach of Antarctic toothfish suggest this technique as a promising tool to identify cephalopod species in the Southern Ocean. Given the major role of cephalopods in the Southern Ocean ecosystem, this study contributes to a better knowledge of the biodiversity and biogeography of these organisms in the Amundsen and D'Urville Seas of the Southern Ocean, and may aid future studies on the structure and functioning of Antarctic marine food webs.

\section{Funding}

JQ was supported by FCT/MCTES through national funds (PIDDAC) and Portuguese Polar Program (PROPOLAR). JQ onboard period was supported by NEP Japan. BD was supported by Investigator FCT program contract CEECIND/00511/2017. AF was supported by Investigator FCT program contract IF/008109/2015. FM was supported by the postdoc FCT grant SFRH/BPD/114664/2016. The work is funded by FCT through the strategic project UID/MAR/04292/2020, granted to MARE, and from SCAR-EGBAMM and ICED.

\section{Declaration of competing interest}

The authors declare that they have no known competing financial interests or personal relationships that could have appeared to influence the work reported in this paper.

\section{Acknowledgements}

The authors would like to thank the crew of FV Antarctic Discovery for its help during sample collection. We also thank NEP Japan for financial support and Australian Longline for accepting JQ on board of its vessel. JQ was supported by FCT/MCTES through national funds (PIDDAC) and Portuguese Polar Program (PROPOLAR). JX acknowledges the support received from Fundação para a Ciência e Tecnologia (FCT, Portugal), through the strategic project UID/MAR/04292/2020, granted to MARE, and from SCAR-EGBAMM and ICED. BD and AF were supported by Investigator FCT programs contracts (CEECIND/00511/ 2017 and IF/008109/2015), FM through the post-doc grant SFRH/BPD/ 114664/2016, funded by Fundação para a Ciência e a Tecnologia (Portugal). Authors would like to thank both reviewers for their valuable comments in the manuscript.

\section{Appendix A. Supplementary data}

Supplementary data to this article can be found online at https://doi. org/10.1016/j.dsr.2021.103571.

\section{References}

Allcock, A.L., 2014. Southern Ocean octopuses. In: De Broyer, C., Koubbi, P., Griffiths, H., Raymond, B., D'Acoz, C.U., Van de Putte, A., Danis, B., David, B., Grant, S., Gutt, J., Held, C., Hosie, G., Huettmann, F., Post, A., Ropert-Coudert, Y. (Eds.), Biogeographic Atlas of the Southern Ocean. The Scientific Committee on Antarctic Research, Cambridge, UK, pp. 129-133.

Allcock, A.L., Hochberg, F.G., Stranks, T.N., 2003. Re-evaluation of Graneledone setebos (Cephalopoda: Octopodidae) and allocation to the genus Megaleledone. J. Mar. Biol. Assoc. U. K. 83, 319-328. https://doi.org/10.1017/S0025315403007148h.

Barbato, M., Kovacs, T., Coleman, M.A., Broadhurst, M.K., de Bruyn, M., 2019. Metabarcoding for stomach-content analyses of Pygmy devil ray (Mobula kuhlii cf. 
eregoodootenkee) : comparing tissue and ethanol preservative-derived DNA. Ecol. Evol. 9, 2678-2687. https://doi.org/10.1002/ece3.4934.

Benson, D.A., Cavanaugh, M., Clark, K., Karsch-Mizrachi, I., Lipman, D.J., Ostell, J., Sayers, E.W., 2013. GenBank. Nucleic Acids Res. 41, 36-42. https://doi.org/ 10.1093/nar/gks1195.

Blankenship, L.E., Yayanos, A.A., 2005. Universal primers and PCR of gut contents to study marine invertebrate diets. Mol. Ecol. 14, 891-899. https://doi.org/10.1111/ j.1365-294X.2005.02448.x.

Borges, A., Rosa, M.S., Recchia, G.H., de Queiroz-Silva, J.R., Bressan, E.A., Veasey, E.A., 2009. CTAB methods for DNA extraction of sweetpotato for microsatellite analysis. Sci. Agric. 66, 529-534. https://doi.org/10.1590/S0103-90162009000400015.

Bowman, R.E., 1986. Effect of regurgitation on stomach content data of marine fishes. Environ. Biol. Fish. 16, 171-181. https://doi.org/10.1007/BF00005169.

Boyle, P., Rodhouse, P., 2005. Cephalopods: Ecology and Fisheries. Blackwell Science Lda, Oxford. https://doi.org/10.1002/9780470995310.

Brault, E.K., Koch, P.L., McMahon, K.W., Broach, K.H., Rosenfield, A.P., Sauthoff, W., Loeb, V.J., Arrigo, K.R., Smith, W.O., 2018. Carbon and nitrogen zooplankton isoscapes in West Antarctica reflect oceanographic transitions. Mar. Ecol. Prog. Ser. 593, 29-45. https://doi.org/10.3354/meps12524.

Buckland, A., Baker, R., Loneragan, N., Sheaves, M., 2017. Standardising fish stomach content analysis: the importance of prey condition. Fish. Res. 196, 126-140. https:// doi.org/10.1016/j.fishres.2017.08.003.

Caddy, J.F., Rodhouse, P.G., 1998. Cephalopod and groundfish landings: evidence for ecological change in global fisheries? Rev. Fish Biol. Fish. 8, 431-444. https://doi. org/10.1023/A:1008807129366.

Carreon-Martinez, L., Johnson, T.B., Ludsin, S.A., Heath, D.D., 2011. Utilization of stomach content DNA to determine diet diversity in piscivorous fishes. J. Fish. Biol. 78, 1170-1182. https://doi.org/10.1111/j.1095-8649.2011.02925.x.

Cherel, Y., 2021. Revisiting taxonomy of cephalopod prey of sperm whales caught commercially in subtropical and Southern Ocean waters. Deep-Sea Res. Part I Oceanogr. Res. Pap. 103490. https://doi.org/10.1016/j.dsr.2021.103490.

Cherel, Y., 2020. A review of Southern Ocean squids using nets and beaks. Mar. Biodivers. 50, 98. https://doi.org/10.1007/s12526-020-01113-4.

Cherel, Y., Duhamel, G., Gasco, N., 2004. Cephalopod fauna of subantarctic islands: new information from predators. Mar. Ecol. Prog. Ser. 266, 143-156. https://doi.org/ 10.3354/meps 266143.

Cherel, Y., Fontaine, C., Jackson, G.D., Jackson, C.H., Richard, P., 2009. Tissue, ontogenic and sex-related differences in $\delta^{13} \mathrm{C}$ and $\delta^{15} \mathrm{~N}$ values of the oceanic squid Todarodes filippovae (Cephalopoda: Ommastrephidae). Mar. Biol. 156, 699-708. https://doi.org/10.1007/s00227-008-1121-x.

Cherel, Y., Hobson, K.A., 2007. Geographical variation in carbon stable isotope signatures of marine predators: a tool to investigate their foraging areas in the Southern Ocean. Mar. Ecol. Prog. Ser. 329, 281-287. https://doi.org/10.3354/ meps329281.

Cherel, Y., Hobson, K.A., 2005. Stable isotopes, beaks and predators: a new tool to study the trophic ecology of cephalopods, including giant and colossal squids. Proc. R. Soc Lond. B Biol. Sci. 272, 1601-1607. https://doi.org/10.1098/rspb.2005.3115.

Cherel, Y., Kooyman, G.L., 1998. Food of emperor penguins (Aptenodytes forsteri) in the western Ross Sea, Antarctica. Mar. Biol. 130, 335-344. https://doi.org/10.1007/ s002270050253.

Cherel, Y., Weimerskirch, H., 1999. Spawning cycle of onychoteuthid squids in the southern Indian Ocean: new information from seabird predators. Mar. Ecol. Prog. Ser. 188, 93-104. https://doi.org/10.3354/meps188093.

Clarke, M.R., 1996. The role of cephalopods in the world's oceans: an introduction. Philos. Trans. R. Soc. B Biol. Sci. 351, 979-983. https://doi.org/10.1098/ rstb.1996.0088.

Clarke, M.R., 1986. A Handbook for the Identification of Cephalopod Beaks, Marine Bio. Clarendon Press, Oxford.

Clarke, M.R., 1980. Cephalopoda in the diet of sperm whales of the Southern hemisphere and their bearing on sperm whale biology. In: Discovery Reports. Institute of Oceanographic Sciences, Plymouth, p. 324.

Clarke, M.R., 1962. Significance of cephalopod beaks. Nature 193, 560-561. https://doi. org/10.1038/193560a0.

Clarke, M.R., Martins, H.R., Pascoe, P., 1993. The diet of sperm whales (Physeter macrocephalus Linnaeus 1758) off the Azores. Phil. Trans. Roy. Soc. Lond. B 339, 67-82. https://doi.org/10.1098/rstb.1993.0005.

Collins, M., Villanueva, R., 2006. Taxonomy, ecology and behaviour of the cirrate octopods. In: Gibson, R.N., Atkinson, A.R.J., Gordon, J.D.M. (Eds.), Oceanography and Marine Biology: an Annual Review. Taylor \& Franceis, London, pp. 277-322. https://doi.org/10.1201/9781420006391.ch6.

Collins, M.A., Allcock, A.L., Belchier, M., 2004. Cephalopods of the South Georgia slope. J. Mar. Biol. Assoc. U. K. 84, 415-419. https://doi.org/10.1017/ S0025315404009373h.

Collins, M.A., Rodhouse, P.G.K., 2006. Southern Ocean cephalopods. In: Southward, A.J., Young, C.M., Fuiman, L.A. (Eds.), Advances in Marine Biology. Academic Press Ltd Elsevier Science Ltd, England, pp. 191-265. https://doi.org/10.1016/S0065-2881 (05)50003-8.

Collins, M.A., Ross, K.A., Belchier, M., Reid, K., 2007. Distribution and diet of juvenile Patagonian toothfish on the South Georgia and Shag Rocks shelves (Southern Ocean). Mar. Biol. 152, 135-147. https://doi.org/10.1007/s00227-007-0667-3.

Dede, A., Salman, A., Tonay, A.M., 2016. Stomach contents of by-caught striped dolphins (Stenella coeruleoalba) in the eastern Mediterranean Sea. J. Mar. Biol. Assoc. U. K. 96, 869-875. https://doi.org/10.1017/S0025315415001538.

Drazen, J.C., Sutton, T.T., 2017. Dining in the deep: the feeding ecology of deep-sea fishes. Ann. Rev. Mar. Sci. 9, 337-366. https://doi.org/10.1146/annurev-marine010816-060543.
Fenaughty, J.M., Stevens, D.W., Hanchet, S.M., 2003. Diet of Antarctic toothfish (Dissostichus mawsoni) from the Ross Sea, Antarctica (subarea 88.1). CCAMLR Sci. 10, 113-123.

Filippova, J.A., 1972. New data on the squids (Cephalopoda: Oegopsida) from the Scotia Sea (Antarctic). Malacologia 11, 391-406. https://doi.org/10.5962/bhl.part.9206.

Filippova, J.A., Pakhomov, E.A., 1994. Young squid in the plankton of Prydz Bay, Antarctica. Antarct. Sci. 6, 171-173. https://doi.org/10.1017/ S095410209400026X.

Folmer, O., Black, M., Hoeh, W., Lutz, R., Vrijenhoek, R., 1994. DNA primers for amplification of mitochondrial cytochrome c oxidase subunit I from diverse metazoan invertebrates. Mol. Mar. Biol. Biotechnol. 3, 294-299.

Garcia, A., 2010. Comparative study of the morphology and anatomy of octopuses of the family Octopodidae. In: Earth Ocean. Sci. Res. Inst. Auckland University of Technology.

García de la Rosa, S.B., Sánchez, F., Figueroa, D., 1997. Comparative feeding ecology of Patagonian toothfish (Dissostichus eleginoides) in the Southwestern Atlantic. CCAMLR Sci. 4, 105-124.

Gebhardt, K., Knebelsberger, T., 2015. Identification of cephalopod species from the North and Baltic Seas using morphology, COI and 18S rDNA sequences. Helgol. Mar. Res. 69, 259-271. https://doi.org/10.1007/s10152-015-0434-7.

Goldsworthy, S.D., Lewis, M., Williams, R., He, X., Young, J.W., van de Hoff, J., 2002. Diet of Patagonian toothfish (Dissostichus eleginoides) around Macquarie Island, South Pacific Ocean. Mar. Freshw. Res. 53, 49-57. https://doi.org/10.1071/ mf00075.

Griffiths, H.J., 2010. Antarctic Marine Biodiversity - What do we know about the distribution of life in the Southern Ocean? PLoS One 5, e11683. https://doi.org/ 10.1371/journal.pone.0011683.g001.

Guerra, A., Rodríguez-Navarro, A.B., González, A.F., Romanek, C.S., Álvarez-Lloret, P., Pierce, G.J., 2010. Life-history traits of the giant squid Architeuthis dux revealed from stable isotope signatures recorded in beaks. ICES J. Mar. Sci. 67, 1425-1431. https://doi.org/10.1093/icesjms/fsq091.

Gutt, J., Isla, E., Xavier, J.C., Adams, B.J., Ahn, I.-Y., Cheng, C.-H.C., Colesie, C., Cummings, V.J., di Prisco, G., Griffiths, H., Hawes, I., Hogg, I., McIntyre, T., Meiners, K.M., Pearce, D.A., Peck, L., Piepenburg, D., Reisinger, R.R., Saba, G.K., Schloss, I.R., Signori, C.N., Smith, C.R., Vacchi, M., Verde, C., Wall, D.H., 2021. Antarctic ecosystems in transition - life between stresses and opportunities. Biol. Rev. 96 (3), 798-821. https://doi.org/10.1111/brv.12679.

Hall, T.A., 1999. BioEdit: a user-friendly biological sequence alignment editor and analysis program for Windows 95/98/NT. Nucleic Acids Symp. Ser. 41, 95-98.

Hanchet, S., Dunn, A., Parker, S., Horn, P., Stevens, D., Mormede, S., 2015. The Antarctic toothfish (Dissostichus mawsoni): biology, ecology, and life history in the Ross Sea region. Hydrobiologia 761, 397-414. https://doi.org/10.1007/s10750-015-2435-6.

Hanchet, S.M., Rickard, G.J., Fenaughty, J.M., Dunn, A., Williams, M.J.H., 2008. A hypothetical life cycle for Antarctic toothfish (Dissostichus mawsoni) in the Ross Sea region. CCAMLR Sci. 15, 35-53.

Hebert, P.D., Ratnasingham, S., deWaard, J.R., 2003. Barcoding animal life: cytochrome c oxidase subunit 1 divergences among closely related species. Proc. R. Soc. B 270, S96-S99. https://doi.org/10.1098/rsbl.2003.0025.

Hobson, K.A., Cherel, Y., 2006. Isotopic reconstruction of marine food webs using cephalopod beaks: new insight from captively raised Sepia officinalis. Can. J. Zool 84, 766-770. https://doi.org/10.1139/z06-049.

Hoving, H.J., Perez, J.A., Bolstad, K.S., Braid, H.E., Evans, A.B., Fuchs, D., Judkins, H., Kelly, J.T., Marian, J.E., Nakajima, R., Piatkowski, U., Reid, A., Vecchione, M., Xavier, J.C., 2014. The study of deep-sea cephalopods. Adv. Mar. Biol. 67, 235-359. https://doi.org/10.1016/B978-0-12-800287-2.00003-2.

Hoving, H.J.T., Bush, S.L., Haddock, S.H.D., Robison, B.H., 2017. Bathyal feasting: postspawning squid as a source of carbon for deep-sea benthic communities. Proc. R. Soc. B 284, 20172096. https://doi.org/10.1098/rspb.2017.2096.

Hunt, J.C., Seibel, B.A., 2000. Life history of Gonatus onyx (Cephalopoda: Teuthoidea) ontogenetic changes in habitat, behavior and physiology. Mar. Biol. 136, 543-552. https://doi.org/10.1007/s002270050714.

Jaeger, A., Lecomte, V.J., Weimerskirch, H., Richard, P., Cherel, Y., 2010. Seabird satellite tracking validates the use of latitudinal isoscapes to depict predators' foraging areas in the Southern Ocean. Rapid Commun. Mass Spectrom. 24, 3456-3460. https://doi.org/10.1002/rcm.4792.

Jo, H.S., Yeon, I., Lim, C., Hanchet, S., Lee, D.W., Kang, C.K., 2013. Fatty acid and stable isotope analyses to infer diet of Antarctic toothfish caught in the southern Ross Sea. CCAMLR Sci. 20, 21-36.

Kear, A.J., 1992. The diet of Antarctic squid: comparison of conventional and serological gut contents analyses. J. Exp. Mar. Biol. Ecol. 156, 161-173. https://doi.org/ 10.1016/0022-0981(92)90243-4.

Kousteni, V., Karachle, P.K., Megalofonou, P., Lefkaditou, E., 2018. Cephalopod prey of two demersal sharks caught in the Aegean Sea (eastern Mediterranean). J. Mar. Biol. Assoc. U. K. 98, 81-88. https://doi.org/10.1017/S002531541700159X.

Lefkaditou, E., Poulopoulos, Y., 1998. Cephalopod remains in the stomach-content of beaked whales, Ziphius cavirostris (Cuvier, 1823) from the Ionian Sea. Rapp. Comm. Int. pour l'Exploration Sci. la Mer Méditerranée 35, 460-461.

Lu, C.C., Ickeringill, R., 2002. Cephalopod beak identification and biomass estimation techniques: tools for dietary studies of southern Australian finfishes. Museum Victoria Sci. Rep. 6, 1-65. https://doi.org/10.24199/j.mvsr.2002.06.

Lu, C.C., Williams, R., 1994a. Contribution to the biology of squid in the Prydz Bay region, Antarctica. Antarct. Sci. 6, 223-229. https://doi.org/10.1017/ S0954102094000349.

Lu, C.C., Williams, R., 1994b. Kondakovia longimana Filippova, 1982 (Cephalopoda: Onychoteuthidae) from the Indian Ocean sector of the Southern Ocean. Antarct. Sci. 6, 231-234. https://doi.org/10.1017/S0954102094000350. 
Matias, R.S., Gregory, S., Ceia, F.R., Baeta, A., Seco, J., Rocha, M.S., Fernandes, E.M., Reis, R.L., Silva, T.H., Pereira, E., Piatkowski, U., Ramos, J.A., Xavier, J.C., 2019. Show your beaks and we tell you what you eat: different ecology in sympatric Antarctic benthic octopods under a climate change context. Mar. Environ. Res. 150, 104757. https://doi.org/10.1016/j.marenvres.2019.104757.

McCutchan, J.H., Lewis, W.M., Kendall, C., McGrath, C.C., 2003. Variation in trophic shift for stable isotope ratios of carbon, nitrogen, and sulfur. OIKOS 102, 378-390. https://doi.org/10.1034/j.1600-0706.2003.12098.x.

Miserez, A., Schneberk, T., Sun, C., Zok, F.W., Waite, J.H., 2008. The transition from stiff to compliant materials in squid beaks. Science 319 (80), 1816-1819. https://doi. org/10.1126/science.1154117.

Moran, Z., Orth, D.J., Schmitt, J.D., Hallerman, E.M., Aguilar, R., 2015. Effectiveness of DNA barcoding for identifying piscine prey items in stomach contents of piscivorous catfishes. Environ. Biol. Fish. 99, 161-167. https://doi.org/10.1007/s10641-0150448-7.

Nemoto, T., Okiyama, M., Iwasaki, N., Kikuchi, T., 1988. Squid as predators on krill (Euphausia superba) and prey for sperm whales in the Southern Ocean. In: Sahrhage, D. (Ed.), Antarctic Ocean and Resources Variability. Springer-Verlag, Berlin Heidelberg, pp. 292-296.

Offredo, C., Ridoux, V., 1985. The diet of Emperor Penguins Aptenodytes forsteri in Adélie Land, Antarctica. Ibis 128, 409-413. https://doi.org/10.1111/j.1474-919X.1986. tb02690.x.

Peterson, B.J., Fry, B., 1987. Stable isotopes in ecosystem studies. Annu. Rev. Ecol. Systemat. 18, 293-320. https://doi.org/10.1146/annurev.es.18.110187.001453.

Piatkowski, U., Pierce, G., Morais da Cunha, M., 2001. Impact of cephalopods in the food chain and their interaction with the environment and fisheries: an overview. Fish. Res. 52, 5-10. https://doi.org/10.1016/S0165-7836(01)00226-0.

Pilling, G.M., Purves, M.G., Daw, T.M., Agnew, D.A., Xavier, J.C., 2001. The stomach contents of Patagonian toothfish around South Georgia (South Atlantic). J. Fish. Biol. 59, 1370-1384. https://doi.org/10.1111/j.1095-8649.2001.tb00198.x.

Potier, M., Ménard, F., Cherel, Y., Lorrain, A., Sabatié, R., Marsac, F., 2007. Role of pelagic crustaceans in the diet of the longnose lancetfish (Alepisaurus ferox) in the Seychelles waters. Afr. J. Mar. Sci. 29, 113-122. https://doi.org/10.2989/ AJMS.2007.29.1.10.75.

Queirós, J., Hilário, A., Thompson, D.R., Ceia, F.R., Elliott, G., Walker, K., Cherel, Y., Xavier, J.C., 2021. From warm to cold waters: new insights into the habitat and trophic ecology of Southern Ocean squids throughout their life cycle. Mar. Ecol. Prog. Ser. 659, 113-126. https://doi.org/10.3354/meps13551.

Queirós, J.P., Cherel, Y., Ceia, F.R., Hilário, A., Roberts, J., Xavier, J.C., 2018. Ontogenic changes in habitat and trophic ecology in the Antarctic squid Kondakovia longimana derived from isotopic analysis on beaks. Polar Biol. 41, 2409-2421. https://doi.org/ 10.1007/s00300-018-2376-4.

Queirós, J.P., Fenwick, M., Stevens, D.W., Cherel, Y., Ramos, J.A., Xavier, J.C., 2020. Ontogenetic changes in habitat and trophic ecology of the giant Antarctic octopus Megaleledone setebos inferred from stable isotope analyses in beaks. Mar. Biol. 167, 56. https://doi.org/10.1007/s00227-020-3666-2.

Queirós, J.P., Phillips, R.A., Baeta, A., Abreu, J., Xavier, J.C., 2019. Habitat, trophic levels and migration patterns of the short-finned squid Illex argentinus from stable isotope analysis of beak regions. Polar Biol. 42, 2299-2304. https://doi.org/ 10.1007/s00300-019-02598-x.

Ratnasingham, S., Hebert, D.N., 2007. BOLD: the barcode of life data system. Mol. Ecol. Notes 7, 355-364. https://doi.org/10.1111/j.1471-8286.2006.01678.x. www. barcodinglife.org.

Remeslo, A.V., Yakushev, M.R., Laptikhovsky, V., 2015. Alien vs. Predator: interactions between the colossal squid (Mesonychoteuthis hamiltoni) and the Antarctic toothfish (Dissostichus mawsoni). J. Nat. Hist. 49, 2483-2491. https://doi.org/10.1080/ 00222933.2015.1040477.

Ridoux, V., Offredo, C., 1989. The diets of five summer breeding seabirds in Adélie Land, Antarctica. Polar Biol. 9, 137-145. https://doi.org/10.1007/BF00297168.

Roberts, J., Xavier, J.C., Agnew, D.J., 2011. The diet of toothfish species Dissostichus eleginoides and Dissostichus mawsoni with overlapping distributions. J. Fish. Biol. 79, 138-154. https://doi.org/10.1111/j.1095-8649.2011.03005.x.

Rodhouse, P.G., 1990. Cephalopod fauna of the Scotia Sea at South Georgia: potential for commercial exploitation and possible consequences. In: Kerry, K.R., Hempel, G. (Eds.), Antarctic Ecosystems. Springer Berlin Heidelberg, Berlin, Heidelberg, pp. 289-298.

Rodhouse, P.G., Arnbom, T.R., Fedak, M.A., Yeatman, J., Murray, A.W.A., 1992. Cephalopod prey of the southern elephant seal, Mirounga leonina L. Can. J. Zool. 70, 1007-1015. https://doi.org/10.1139/z92-143.

Rodhouse, P.G., Clarke, M.R., 1986. Distribution of the early-life phase of the Antarctic squid Galiteuthis glacialis in relation to the hydrology of the Southern Ocean in the sector $15^{\circ}$ to $30^{\circ} \mathrm{E}$. Mar. Biol. 91, 353-357. https://doi.org/10.1007/BF00428629.

Rodhouse, P.G., Nigmatullin, C.M., 1996. Role as consumers. Philos. Trans. R. Soc. B 351, 1003-1022. https://doi.org/10.1098/rstb.1996.0090.

Rodhouse, P.G., Prince, P.A., Trathan, P.N., Hatfield, E.M.C., Watkins, J.L., Bone, D.G., Murphy, E.J., White, M.G., 1996. Cephalopods and mesoscale oceanography at the Antarctic Polar Front: satellite tracked predators locate pelagic trophic interactions. Mar. Ecol. Prog. Ser. 136, 37-50. https://doi.org/10.3354/meps136037.

Rodhouse, P.G.K., 2013. Role of squid in the Southern Ocean pelagic ecosystem and the possible consequences of climate change. Deep Sea Res. Part II Top. Stud. Oceanogr. 95, 129-138. https://doi.org/10.1016/j.dsr2.2012.07.001.

Rodhouse, P.G.K., Griffiths, H.J., Xavier, J.C., 2014. Southern Ocean squid. In: De Broyer, C., Koubbi, P., Griffiths, H., Raymond, B., D'Acoz, C.U., Van de Putte, A., Danis, B., David, B., Grant, S., Gutt, J., Held, C., Hosie, G., Huettmann, F., Post, A., Ropert-Coudert, Y. (Eds.), The Biogeographic Atlas of the Southern Ocean. The Scientific Committee on Antarctic Research, Cambridge, UK, pp. 284-289.
Romeo, T., Battaglia, P., Pedà, C., Perzia, P., Consoli, P., Esposito, V., Andaloro, F., 2012. Pelagic cephalopods of the central Mediterranean Sea determined by the analysis of the stomach content of large fish predators. Helgol. Mar. Res. 66, 295-306. https:// doi.org/10.1007/s10152-011-0270-3.

Rosa, R., Lopes, V.M., Guerreiro, M., Bolstad, K.S., Xavier, J.C., 2017. Biology and ecology of the world's largest invertebrate, the colossal squid (Mesonychoteuthis hamiltoni): a short review. Polar Biol. 40, 1871-1883. https://doi.org/10.1007/ s00300-017-2104-5.

Rosel, P.E., Kocher, T.D., 2002. DNA-based identification of larval cod in stomach contents of predatory fishes. J. Exp. Mar. Biol. Ecol. 267, 78-88. https://doi.org/ 10.1016/S0022-0981(01)00359-8.

Santos, M.B., Clarke, M.R., Pierce, G.J., 2001. Assessing the importance of cephalopods in the diets of marine mammals and other top predators: problems and solutions. Fish. Res. 52, 121-139. https://doi.org/10.1016/S0165-7836(01)00236-3.

Schwarz, R., Hoving, H.J., Noever, C., Piatkowski, U., 2019. Life histories of Antarctic incirrate octopods (Cephalopoda: Octopoda). PLoS One 14, e0219694. https://doi. org/10.1371/journal.pone.0219694.

Seco, J., Roberts, J., Ceia, F.R., Baeta, A., Ramos, J.A., Paiva, V.H., Xavier, J.C., 2016. Distribution, habitat and trophic ecology of Antarctic squid Kondakovia longimana and Moroteuthis knipovitchi: inferences from predators and stable isotopes. Polar Biol. 39, 167-175. https://doi.org/10.1007/s00300-015-1675-2.

Smith, P.J., Mcveagh, S.M., Allain, V., Sanchez, C., 2005. DNA identification of gut contents of large pelagic fishes. J. Fish. Biol. 67, 1178-1183. https://doi.org/ 10.1111/j.1095-8649.2005.00804.x.

Stevens, D.W., Dunn, M.R., Pinkerton, M.H., Forman, J.S., 2014. Diet of Antarctic toothfish (Dissostichus mawsoni) from the continental slope and oceanic features of the Ross Sea region, Antarctica. Antarct. Sci. 26, 502-512. https://doi.org/10.1017/ s095410201300093x.

Strugnell, J.M., Allcock, A.L., Watts, P.C., 2017. Closely related octopus species show different spatial genetic structures in response to the Antarctic seascape. Ecol. Evol. 7, 8087-8099. https://doi.org/10.1002/ece3.3327.

Strugnell, J.M., Cherel, Y., Cooke, I.R., Gleadall, I.G., Hochberg, F.G., Ibáñez, C.M., Jorgensen, E., Laptikhovsky, V.V., Linse, K., Norman, M., Vecchione, M., Voight, J. R., Allcock, A.L., 2011. The Southern Ocean: source and sink? Deep Sea Res. Part II Top. Stud. Oceanogr. 58, 196-204. https://doi.org/10.1016/j.dsr2.2010.05.015.

Strugnell, J.M., Rogers, A.D., Prodöhl, P.A., Collins, M.A., Allcock, A.L., 2008. The thermohaline expressway: the Southern Ocean as a centre of origin for deep-sea octopuses. Cladistics 24, 853-860. https://doi.org/10.1111/j.10960031.2008.00234.x.

Strugnell, J.M., Watts, P.C., Smith, P.J., Allcock, A.L., 2012. Persistent genetic signatures of historic climatic events in an Antarctic octopus. Mol. Ecol. 21, 2775-2787. https://doi.org/10.1111/j.1365-294X.2012.05572.x.

Thompson, D.R., Pinkerton, M.H., Stevens, D.W., Cherel, Y., Bury, S.J., 2012. The Ross Sea cephalopod community: insighs from stable isotope analysis. Doc. WG-EMM-12/ 55. CCAMLR, Hobart, Aust 14.

Troccoli, G.H., Aguilar, E., Martínez, P.A., Belleggia, M., 2020. The diet of the Patagonian toothfish Dissostichus eleginoides, a deep-sea top predator off Southwest Atlantic Ocean. Polar Biol. 43, 1595-1604. https://doi.org/10.1007/s00300-02002730-2.

Vecchione, M., Allcock, L., Piatkowski, U., Strugnell, J., 2009. Benthoctopus rigbyae, n. sp., A new species of cephalopod (Octopoda: Incirrata) from near the Antarctic Peninsula. Malacologia 51, 13-28. https://doi.org/10.4002/040.051.0102.

Vecchione, M., Piatkowski, U., Allcock, A.L., 1998. Biology of the cirrate octopod Grimpoteuthis glacialis (Cephalopoda: Opisthoteuthididae) in the South Shetland islands, Antarctica. S. Afr. J. Mar. Sci. 20, 421-428. https://doi.org/10.2989/ 025776198784126467.

Xavier, J.C., Cherel, Y., 2009. Cephalopod Beak Guide for the Southern Ocean. British Antarctic Survey, Cambridge, UK.

Xavier, J.C., Cherel, Y., Allcock, L., Rosa, R., Sabirov, R.M., Blicher, M.E., Golikov, A.V., 2018. A review on the biodiversity, distribution and trophic role of cephalopods in the Arctic and Antarctic marine ecosystems under a changing ocean. Mar. Biol. 165 https://doi.org/10.1007/s00227-018-3352-9.

Xavier, J.C., Croxall, J.P., 2007. Predator-prey interactions: why do larger albatrosses eat bigger squid? J. Zool. 271, 408-417. https://doi.org/10.1111/j.14697998.2006.00224.x.

Xavier, J.C., Ferreira, S., Tavares, S., Santos, N., Mieiro, C.L., Trathan, P.N., Lourenço, S., Martinho, F., Steinke, D., Seco, J., Pereira, E., Pardal, M., Cherel, Y., 2016a. The significance of cephalopod beaks in marine ecology studies: can we use beaks for DNA analyses and mercury contamination assessment? Mar. Pollut. Bull. 103, 220-226. https://doi.org/10.1016/j.marpolbul.2015.12.016.

Xavier, J.C., Raymond, B., Jones, D.C., Griffiths, H., 2016b. Biogeography of cephalopods in the Southern Ocean using habitat suitability prediction models. Ecosystems 19, 220-247. https://doi.org/10.1007/s10021-015-9926-1.

Xavier, J.C., Rodhouse, P.G., Purves, M.G., Daw, T.M., Arata, J., Pilling, G.M., 2002. Distribution of cephalopods recorded in the diet of the Patagonian toothfish (Dissostichus eleginoides) around South Georgia. Polar Biol. 25, 323-330. https://doi. org/10.1007/s00300-001-0343-x.

Xavier, J.C., Walker, K., Elliot, G., Cherel, Y., Thompson, D., 2014. Cephalopod fauna of South Pacific waters: new information from breeding New Zealand wandering albatrosses. Mar. Ecol. Prog. Ser. 513, 131-142. https://doi.org/10.3354/ meps10957.

Yoon, T.H., Kang, H.E., Lee, S.R., Lee, J.B., Baeck, G.W., Park, H., Kim, H.W., 2017. Metabarcoding analysis of the stomach contents of the antarctic toothfish (Dissostichus mawsoni) collected in the Antarctic Ocean. PeerJ 5, e3977. https://doi. org/10.7717/peerj.3977. 